OPEN ACCESS

Edited by:

Gang Rao,

Southwest Petroleum University,

China

Reviewed by:

Kai Cao,

China University of Geosciences

Wuhan, China

Robert Emberson,

University of Maryland, Baltimore

County, United States

${ }^{*}$ Correspondence:

Laifeng $\mathrm{Li}$

lilaifeng@nju.edu.cn

Specialty section:

This article was submitted to Structural Geology and Tectonics,

a section of the journal

Frontiers in Earth Science

Received: 01 December 2021

Accepted: 03 February 2022

Published: 02 March 2022

Citation:

Li L, Li GK, Li L and Li G (2022) Landslide-Induced Weathering in

Tectonically Active Mountains: Evidence From Dissolved Radiogenic Uranium Isotopes.

Front. Earth Sci. 10:825818. doi: 10.3389/feart.2022.825818

\section{Landslide-Induced Weathering in Tectonically Active Mountains: Evidence From Dissolved Radiogenic Uranium Isotopes}

\author{
Laifeng $L i^{1,2,3 *}$, Gen K. $L i^{4}$, Le $L i^{1,3}$ and Gaojun $L i^{1,3}$ \\ ${ }^{1}$ MOE Key Laboratory of Surficial Geochemistry, Department of Earth and Planetary Sciences, Nanjing University, Nanjing, China, \\ ${ }^{2}$ School of Geography and Ocean Science, Nanjing University, Nanjing, China, ${ }^{3}$ Frontiers Science Center for Critical Earth Material \\ Cycling, Nanjing University, Nanjing, China, ${ }^{4}$ Department of Earth Science, University of California, Santa Barbara, CA, \\ United States
}

Understanding weathering processes in landslide-dominated catchments is critical for evaluating the role of landslides in chemical weathering and the global carbon cycle. Previous studies have focused on solute concentrations in landslide-impacted landscapes, but have paid less attention to developing isotopic tracers of landslideinduced weathering fluxes. Recent work found that the dissolved radiogenic uranium isotopes in river water are closely related to the denudation rates in catchments draining steep mountains where landslides are thought to be a major erosion mechanism, suggesting the potential of uranium isotopes to trace landslide-induced weathering fluxes. Here we compile the dissolved radiogenic uranium isotopes $\left({ }^{234} \mathrm{U} /{ }^{238} \mathrm{U}\right.$ ratios) in the river water samples from a group of catchments with variable landslide activities in the Minjiang River Basin at the eastern margin of the Tibetan Plateau. We derive three metrics of landslide activity from the analyses of digital topography and an inventory map of the coseismic landslides triggered by the 2008 Mw7.9 Wenchuan earthquake: the normalized volume of landslides, the mean catchment slope angle, and the fraction of slopes steeper than a threshold angle beyond which slopes are mechanically unstable. The riverine dissolved ${ }^{234} \mathrm{U} /{ }^{238} \mathrm{U}$ ratios correlate negatively with the metrics of landslide activity in each catchment, which likely reflect the influence of landslides on the dissolved ${ }^{234} U /{ }^{238} \mathrm{U}$ ratios. Mechanistically, enhanced bedrock landsliding would accelerate the exposure of fresh rock, promoting bedrock weathering and congruent dissolution of ${ }^{234} U$ and ${ }^{238} U$ contained in minerals; reduced landslide activities and enhanced regolith weathering would lead to preferential accumulation of ${ }^{234} \mathrm{U}$ against ${ }^{238} \mathrm{U}$ in solutes through alpharecoil ejection, thus increasing dissolved ${ }^{234} \mathrm{U} /{ }^{238} \mathrm{U}$. Our findings provide field evidence of using the riverine dissolved ${ }^{234} \mathrm{U} /{ }^{238} \mathrm{U}$ ratio to trace weathering fluxes driven by landslides, shedding new light on chemical weathering processes in uplifting mountains.

Keywords: landslide, chemical weathering, uranium isotope, tectonically active mountains, tectonic uplift 


\section{INTRODUCTION}

In uplifting mountains, hillslopes steepen in response to channel incision and become prone to landslides once hillslopes are steeper than the angle of repose (Burbank et al., 1996; Ouimet et al., 2008; Larsen and Montgomery, 2012). In seismically active regions, the seismic ground motion also induces landslides that erode topography and counteract seismic uplift (Keefer, 1994; Parker et al., 2011; Marc et al., 2016; Li G. et al., 2019). As a legacy of tectonic uplift, landslides have profound influences on Earth's surface environments, from generating hazards to exporting sediment and organic carbon fluxes (Fan et al., 2019; Croissant et al., 2021). Besides these recognitions, major research efforts have been devoted to studying how landslides impact chemical weathering-a key process governing the exchange of carbon between the atmosphere and lithosphere (Emberson et al., 2016; Jin et al., 2016; Emberson et al., 2017; Emberson et al., 2018). Because landslides have been identified as a primary mechanism of erosion in steep mountains (Hovius et al., 1997; Larsen and Montgomery, 2012; Li G. et al., 2017; Marc et al., 2019), the linkage between landslide activity and chemical weathering holds key implications for the interplay between tectonic uplift, erosion, and the carbon cycle. Understanding this linkage requires effective tracers of landslide-induced weathering fluxes (e.g., Li et al., 2018; Li S. et al., 2019), which have received less attention. Studies have used total dissolved solids (TDS, Emberson et al., 2016), elemental composition (Jin et al., 2016), and ${ }^{10} \mathrm{Be}$ (meteoric) $/{ }^{9} \mathrm{Be}$ (Deng et al., 2021) to examine landslide-induced weathering, but we are still lacking tracers of the weathering of fresh bedrock exposed during landsliding. In the previously used tracers, TDS and elemental concentrations are sensitive to lithologic variations and are easily influenced by rainfall-related dilution effects (e.g., Gaillardet et al., 1999; Torres et al., 2015). Using ${ }^{10} \mathrm{Be}$ (meteoric) $/{ }^{9} \mathrm{Be}$ to trace weathering processes relies on robust constraints on the absorption coefficients of ${ }^{10} \mathrm{Be}$ to different minerals (von Blanckenburg et al., 2012).

The radiogenic uranium isotopes $\left({ }^{234} \mathrm{U}\right.$ and $\left.{ }^{238} \mathrm{U}\right)$ in river water provide a promising tool to trace weathering fluxes from landslide debris. The ${ }^{234} \mathrm{U} /{ }^{238} \mathrm{U}$ ratios of river water are controlled by the competition between the direct recoil ejection of ${ }^{234} \mathrm{Th}$ associated with alpha-decay of ${ }^{238} \mathrm{U}$ and the preferential dissolution of ${ }^{234} \mathrm{U}$ from lattices that have been radioactively damaged by alpha-decay of ${ }^{238} \mathrm{U}$ (Bourdon et al., 2003; Chabaux et al., 2003; Li et al., 2018). It is suggested that the significant influence of preferential dissolution of ${ }^{234} \mathrm{U}$ on riverine ${ }^{234} \mathrm{U} /{ }^{238} \mathrm{U}$ ratios is only applied to regions with extremely high erosion rates, such as Taiwan and New Zealand (Li et al., 2018). Meanwhile, studies show that the riverine ${ }^{234} \mathrm{U} /{ }^{238} \mathrm{U}$ ratio is closely related to catchment-scale denudation rates (Robinson et al., 2004; Vigier et al., 2006; Li et al., 2018), and those relationships are likely caused by the differential weathering of fresh bedrock and aged regolith (Li et al., 2018). In rapidly eroding catchments where landslides dominate erosion budgets (Hovius et al., 1997; Larsen and Montgomery, 2012; Li G. et al., 2017; Marc et al., 2019), landsliding promotes the exposure of fresh bedrocks and

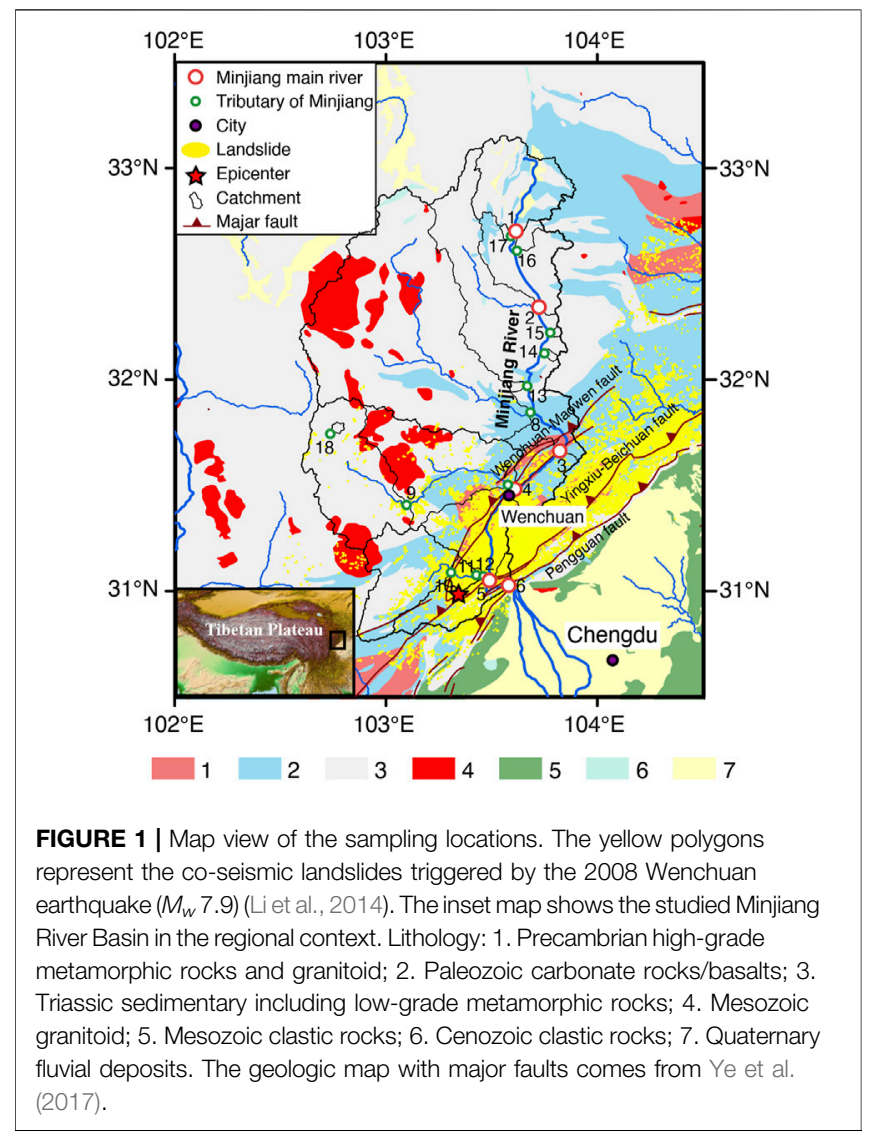

minerals (Emberson et al., 2018), likely accelerating chemical weathering and causing congruent dissolution of ${ }^{234} \mathrm{U}$ and ${ }^{238} \mathrm{U}$ contained in minerals, leading to a near-equilibrium ${ }^{234} \mathrm{U} /{ }^{238} \mathrm{U}$ activity ratio $(\sim 1)$. In slowly eroding catchments where landslides occur less frequently, weathering mostly occurs in regolith which has a long residence time in the catchments (West et al., 2005) to allow the preferential accumulation of ${ }^{234} \mathrm{U}$ versus ${ }^{238} \mathrm{U}$ in solutes through the alpha-recoil ejection of ${ }^{238} \mathrm{U}$, causing a higher ${ }^{234} \mathrm{U} /$ ${ }^{238} \mathrm{U}$ ratio of river water (Chabaux et al., 2003; Li et al., 2018). Therefore, the riverine dissolved ${ }^{234} \mathrm{U} /{ }^{238} \mathrm{U}$ ratio has the potential to trace the weathering of freshly exposed bedrock and rock debris, which are commonly related to landsliding.

The 2008 Wenchuan earthquake $\left(M_{w} 7.9\right)$ triggered extensive landslides in the Minjiang River Basin (Figure 1, Parker et al., 2011; Li et al., 2014), providing a unique opportunity to test the riverine ${ }^{234} \mathrm{U} /{ }^{238} \mathrm{U}$ ratio as a tracer of landslide-driven weathering. In this work, we compiled the dissolved ${ }^{234} \mathrm{U} /{ }^{238} \mathrm{U}$ ratios in river water samples from a group of catchments draining the epicentral region of the Wenchuan earthquake from a prior study ( $\mathrm{Li}$ et al., 2018). We derived three metrics of landslide activity and propensity from a landslide inventory map and digital topography and compared those metrics to the compiled riverine ${ }^{234} \mathrm{U} /{ }^{238} \mathrm{U}$ to validate the dissolved uranium isotopes as a tracer of landslide-induced weathering. Lastly, we discussed the implications of landslide-induced weathering for the 'uplift-weathering' hypothesis and theories of weathering kinetic. 


\section{SETTINGS, MATERIALS, AND METHODS}

\section{Settings}

We focused on the Minjiang River Basin at the eastern border of the Tibetan Plateau. The $2008 M_{w} 7.9$ Wenchuan earthquake occurred in the river basin and induced massive co-seismic landslides (Figure 1, Parker et al., 2011; Li et al., 2014). The bedrock geology in the Minjiang River Basin is characterized by Precambrian high-grade metamorphic rocks, Paleozoic carbonate rocks, and Triassic sedimentary sequences including low-grade metamorphic rocks (Figure 1). The river network in the Minjiang River Basin drained landscapes across a gradient of landslide activities (Li et al., 2016).

\section{U Isotope and Water Chemistry Data Compilation}

The dissolved ${ }^{234} \mathrm{U} /{ }^{238} \mathrm{U}$ dataset in the Minjiang River Basin was adopted from a global compilation of riverine ${ }^{234} \mathrm{U} /{ }^{238} \mathrm{U}$ data $(\mathrm{Li}$ et al., 2018). We summarized their sampling and measurement procedures below. In short, 12 water samples from the Minjiang River tributaries and 6 water samples along the mainstream of the Minjiang River were collected in June 2015 and August 2016 (Figure 1). For each sample, around $1 \mathrm{~L}$ of river water was collected and filtered through $0.22 \mu \mathrm{m}$ cellulose acetate membrane filters. A split of the filtered sample was acidified to $\mathrm{pH}<2$ using $15 \mathrm{M} \mathrm{HNO}_{3}$ and stored below $5^{\circ} \mathrm{C}$ for uranium isotope measurements. The uranium in the water samples was separated using UTEVA resin (100-150 mesh), following the method in Wang and You (2013). The $\left({ }^{234} \mathrm{U} /{ }^{238} \mathrm{U}\right)$ ratios were measured by an MC-ICP-MS (Neptune Plus) following the protocol of Li L. et al. (2017). The standard seawater IAPSO was measured to check the accuracy of measurement, giving $\left({ }^{234} \mathrm{U} /{ }^{238} \mathrm{U}\right)$ ratios of $1.144 \pm 0.002$ and $1.143 \pm 0.001$ (mean $\pm 2 \times$ standard error), consistent with the long-term measurement value of $1.143 \pm 0.004$ ( $\mathrm{Li}$ et al., 2018) of the laboratory and the recommended value of $1.144 \pm 0.004$ (Wang and You, 2013).

In this work, we complemented the $U$ isotope analysis by measuring the cations and anions of the aliquots of the same set of samples collected by Li et al. (2018). The cation $\left(\mathrm{K}^{+}, \mathrm{Ca}^{2+}, \mathrm{Na}^{+}\right.$, $\mathrm{Mg}^{2+}$ ) and dissolved $\mathrm{Si}$ concentrations were measured on the acidified splits of the filtered river water samples using an inductively coupled plasma-optical emission spectrometer (ICP-OES, iCAP-6300). The anions $\left(\mathrm{F}^{-}, \mathrm{Cl}^{-}, \mathrm{NO}_{3}{ }^{-}, \mathrm{SO}_{4}{ }^{2-}\right)$ were measured on the un-acidified splits using an ionic Chromatography System (Dionex ICS-1100). The measurement uncertainties were less than $\pm 5 \%$ (2 SD) based on repeated analyses of the samples and standards. The contribution of the atmospheric input to $\mathrm{Na}$ is corrected by:

$$
[\mathrm{Na}]^{*}=[\mathrm{Na}]-[\mathrm{Cl}]
$$

where $[\mathrm{Na}]^{*},[\mathrm{Na}]$ and $[\mathrm{Cl}]$ represent the concentrations of atmosphere-input-corrected $\mathrm{Na}$, uncorrected $\mathrm{Na}$, and $\mathrm{Cl}$ in river water, respectively. The alkalinities in the unfiltered water samples were titrated in the field by hydrochloric acid using methyl orange as an indicator for the endpoint $(\mathrm{pH}=4.4)$. The
TDS (mg/L) of all water samples was calculated by summing the concentrations of cations, dissolved $\mathrm{Si}$, anions, and alkalinities.

\section{Topographic Analysis}

We extracted 18 catchments upstream of the sampling sites using the hydrological toolbox in ArcMap 10.2 and the ASTGTM2 digital elevation model (DEM) with 30-m resolution (https:// lpdaac.usgs.gov/products/astgtmv002/). We computed three metrics to represent landslide activity and propensity in each catchment. First, we adopted the Wenchuan co-seismic landslide data from a published landslide inventory (Li et al., 2014), and calculated the normalized volume of landslides $\left(\mathrm{LS}_{\text {norm }}\right)$ in each catchment by normalizing the total volume of the co-seismic landslides that are calculated from a regional landslide area-volume scaling relation (Parker et al., 2011; Li et al., 2014) by the total catchment area. Second, we calculated the mean slope angles of all cells in the catchments as a metric for landslide propensity considering that steeper catchments generally have higher erosion rates and more frequent landslide events (Ouimet et al., 2009; Larsen and Montgomery, 2012). Third, we quantified the fraction of cells inclined at angles steeper than a threshold angle of $32^{\circ}$ whereas those oversteepened cells are prone to failures (Ouimet et al., 2009; Clarke and Burbank, 2010) and term this fraction, $F_{o}$.

\section{RESULTS}

The mean catchment slope angles vary from $24.0^{\circ}$ to $30.1^{\circ}$ for the catchments where the corresponding sampling sites are in the main Minjiang River, with an increasing trend from upper stream to downstream (Table 1). For the sampled tributary catchments, the mean slope angles lie between $23.0^{\circ}$ and $36.1^{\circ}$ (Table 1). Two catchments in the upper stream part of the Minjiang River Basin (corresponding to JGS6 and JGS9) do not have identifiable landslides from the Wenchuan earthquake, but the other four catchments whose corresponding sampling sites are along the main Minjiang River have an increase in the normalized volume of landslides $\left(\mathrm{LS}_{\text {norm }}\right)$ from the upstream (JGS11, $121 \mathrm{~m}^{3} \mathrm{~km}^{-2}$ ) to downstream sites ( $\mathrm{ZPP}, 64100 \mathrm{~m}^{3} \mathrm{~km}^{-2}$ ) (Figure 1 and Table 1). Five sampled tributary catchments have negligible co-seismic landslides triggered by the Wenchuan earthquake, and the other tributary catchments show variable $\mathrm{LS}_{\text {norm }}$ from 115 to $184234 \mathrm{~m}^{3} \mathrm{~km}^{-2}$ (Figure 1 and Table 1). The fraction of slopes steeper than threshold angle $\left(F_{o}\right)$ increases from 21.3 to $44.4 \%$ from upstream to downstream for those sites along the main Minjiang River and varies between 12.7 and 69.1\% (Table 1) for the studied tributary catchments. TDS changes from 176.3 to $322.5 \mathrm{mg} / \mathrm{L}$ (Table 1 ) for the samples from the main Minjiang River with an increase from the upstream to downstream sites, and ranges between 129.4 to $491.7 \mathrm{mg} / \mathrm{L}$ for the tributary catchments (Table 1).

The $\left({ }^{234} \mathrm{U} /{ }^{238} \mathrm{U}\right)$ value of the samples from the main Minjiang River decreases from 1.597 to 1.114 , with higher ${ }^{234} \mathrm{U} /{ }^{238} \mathrm{U}$ ratios from the upstream sites and lower ${ }^{234} \mathrm{U} /{ }^{238} \mathrm{U}$ ratios from the downstream sites (Figure 2 and Table 1). The samples from the 
TABLE 1 | The chemical composition of river water and the riverine geomorphic features in the Minjiang River Basin.

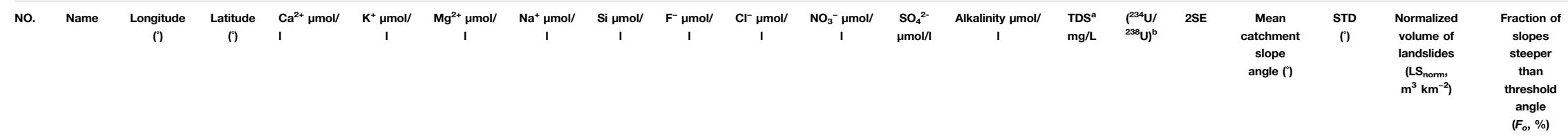

\begin{tabular}{|c|c|c|c|c|c|c|c|c|c|c|c|c|c|c|c|c|c|c|c|c|}
\hline \multicolumn{21}{|c|}{ Minjiang main river } \\
\hline 1 & JGS6 & 103.6037 & 32.6851 & 1,281 & 23.3 & 422 & 139.7 & 92.3 & 4.7 & 31.2 & 24.8 & 79.5 & 3,500 & 294.9 & 1.597 & 0.002 & 24.0 & 10.1 & 0 & 21.3 \\
\hline 2 & JGS9 & 103.7190 & 32.3311 & 1,239 & 23.4 & 644 & 144.7 & 95.2 & 2.8 & 29.5 & 28.6 & 121.0 & 3,820 & 322.5 & 1.370 & 0.001 & 25.5 & 10.1 & 0 & 25.8 \\
\hline 3 & JGS11 & 103.8241 & 31.6599 & 755 & 27.2 & 355 & 122.9 & 90.5 & 5.0 & 33.4 & 28.3 & 136.5 & 2,020 & 187.4 & 1.180 & 0.001 & 28.0 & 10.8 & 121 & 36.2 \\
\hline 4 & JGS4 & 103.7661 & 31.4813 & 760 & 28.0 & 355 & 119.5 & 88.3 & 5.7 & 35.8 & 28.2 & 177.6 & 2,050 & 193.3 & 1.154 & 0.001 & 28.2 & 10.9 & 6764 & 36.9 \\
\hline 5 & Musx & 103.4792 & 31.0422 & 710 & 32.3 & 310 & 111.1 & 90.4 & 3.6 & 24.1 & 24.5 & 165.0 & 1,880 & 178.0 & 1.126 & 0.001 & 30.1 & 11.2 & 61262 & 44.4 \\
\hline 6 & ZPP & 103.5743 & 31.0331 & 726 & 31.4 & 316 & 116.8 & 89.1 & 3.5 & 30.0 & 26.4 & 173.6 & 1,820 & 176.3 & 1.114 & 0.001 & 30.1 & 11.2 & 64100 & 44.4 \\
\hline \multicolumn{21}{|c|}{ Tributaries of Minjiang River } \\
\hline 7 & JGS3 & 103.5729 & 31.5000 & 569 & 34.4 & 203 & 78.6 & 85.9 & 5.5 & 22.4 & 31.1 & 168.9 & 1,220 & 129.4 & 1.044 & 0.001 & 33.2 & 10.9 & 13757 & 57.5 \\
\hline 8 & JGS10 & 103.6838 & 31.8415 & 571 & 19.9 & 216 & 95.8 & 84.9 & 5.1 & 27.5 & 22.7 & 108.9 & 1,320 & 129.5 & 1.155 & 0.001 & 28.6 & 10.9 & 115 & 39.0 \\
\hline 9 & JGS12 & 103.0990 & 31.4031 & 616 & 36.9 & 163 & 75.9 & 87.2 & 6.1 & 17.5 & 27.9 & 130.9 & 1,920 & 169.1 & 1.031 & 0.001 & 32.5 & 10.8 & 6943 & 54.9 \\
\hline \multirow{2}{*}{10} & JGS13 & 103.3069 & 31.0889 & 787 & 31.6 & 296 & 76.3 & 75.5 & 2.4 & 12.4 & 30.0 & 255.4 & 1,780 & 181.5 & 0.989 & 0.001 & 33.0 & 11.6 & 62522 & 55.5 \\
\hline & YZX-U & 103.4253 & 31.0739 & 705 & 31.8 & 208 & 87.8 & 97.9 & 0.8 & 10.9 & 47.1 & 215.8 & 1,420 & 153.0 & 0.994 & 0.001 & 33.3 & 11.6 & 165679 & 56.7 \\
\hline 11 & YZX-D & 103.4514 & 31.0719 & 715 & 60.8 & 171 & 136.9 & 132.6 & 1.8 & 27.4 & 9.2 & 91.2 & 1,450 & 145.0 & 1.001 & 0.001 & 33.4 & 11.7 & 184234 & 56.9 \\
\hline \multirow[t]{2}{*}{12} & & & & & & & & & & & & & & & & & & & & \\
\hline & $\mathrm{AB} 16 \mathrm{H} 33$ & 103.6719 & 31.9744 & 918 & 31.7 & 357 & 87.3 & 85 & 3.1 & 7.5 & 15.9 & 145.1 & 2,340 & 211.6 & 1.069 & 0.001 & 36.1 & 9.1 & 5,809 & 69.1 \\
\hline 13 & $\mathrm{AB} 16 \mathrm{H} 34$ & 103.7375 & 32.1197 & 1,167 & 32.9 & 553 & 142.7 & 92 & 0 & 22.6 & 54.9 & 226.0 & 3,120 & 286.2 & 1.169 & 0.001 & 35.9 & 11.2 & 0 & 65.6 \\
\hline 14 & $\mathrm{AB} 16 \mathrm{H} 35$ & 103.7750 & 32.2175 & 847 & 15.0 & 840 & 91.9 & 67 & 0 & 11.1 & 19.2 & 111.9 & 3,300 & 274.4 & 1.054 & 0.001 & 34.0 & 9.6 & 0 & 60.3 \\
\hline \multirow[t]{2}{*}{15} & & & & & & & & & & & & & & & & & & & & \\
\hline & $\mathrm{AB} 16 \mathrm{H} 36$ & 103.6147 & 32.6081 & 1,272 & 32.0 & 1,270 & 283.5 & 118 & 10.3 & 23.1 & 18.7 & 124.9 & 5,700 & 458.1 & 1.676 & 0.002 & 23.0 & 8.2 & 0 & 12.7 \\
\hline 16 & $\mathrm{AB} 16 \mathrm{H} 37$ & 103.6000 & 32.6769 & 1,404 & 38.0 & 1,251 & 262.3 & 123 & 6.4 & 17.4 & 11.9 & 44.2 & 6,310 & 491.7 & 1.477 & 0.001 & 26.3 & 8.2 & 0 & 23.2 \\
\hline 17 & $\mathrm{AB} 16 \mathrm{H} 40$ & 102.7347 & 31.7492 & 863 & 8.6 & 536 & 94.7 & 81 & 2.5 & 6.0 & 14.9 & 236.0 & 2,800 & 249.4 & 1.114 & 0.001 & 28.4 & 8.5 & 0 & 36.2 \\
\hline
\end{tabular}

${ }^{a}$ TDS (Total dissolved solids) $=\mathrm{Ca}^{2+}+\mathrm{K}^{+}+\mathrm{Mg}^{2+}+\mathrm{Na}^{+}+$Alkalinity $+\mathrm{F}^{-}+\mathrm{Cl}^{-}+\mathrm{NO}_{3}{ }^{-}+\mathrm{SO}_{4}{ }^{2-}+\mathrm{SiO}_{2}$ in $\mathrm{mg} / \mathrm{L}$.

${ }^{b}$ The ${ }^{234} \mathrm{U}^{238} \mathrm{U}$ ) ratios have been published in Li et al. (2018) [NO. 69 to NO. 86 in Table S2 of Li et al. (2018)]. 


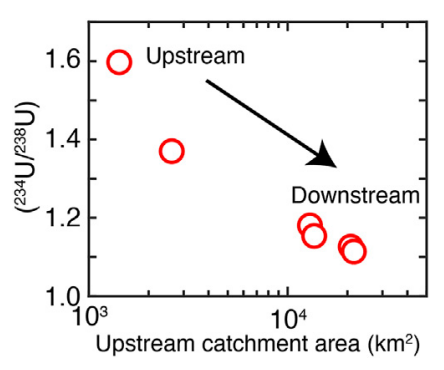

FIGURE 2 | The $\left({ }^{234} \mathrm{U} /{ }^{238} \mathrm{U}\right)$ values of the samples collected along the main Minjiang River from upstream to downstream. The error bar for the $\left({ }^{234} \mathrm{U} /\right.$ ${ }^{238} \mathrm{U}$ ) ratio is smaller than the size of the symbols.

tributary catchments have $\left({ }^{234} \mathrm{U} /{ }^{238} \mathrm{U}\right)$ ratios ranging from 0.989 to 1.676 .

The riverine dissolved $\left({ }^{234} \mathrm{U} /{ }^{238} \mathrm{U}\right)$ ratios have negative correlations with the normalized volume of landslides, the mean catchment slope angle, and the fraction of slopes steeper than threshold angle $\left(32^{\circ}\right)$ in the Minjiang River Basin $(r=-0.70,-0.83$, and -0.85 , respectively, Figures $\mathbf{3 A}, \mathbf{4}$ and Table $\mathbf{1})$. In contrast, opposite trends between $\left({ }^{234} \mathrm{U} /{ }^{238} \mathrm{U}\right)$ ratios and $\mathrm{Ca} / \mathrm{Na}^{*}$ ratios are observed for the mainstream and tributary samples with a positive correlation for mainstream and a negative correlation for tributary (Figure 5). We do not observe statistically significant correlations between TDS and the normalized volume of landslides $\left(\mathrm{LS}_{\text {norm }}\right)$ in the Minjiang River Basin (Figure 3B), unlike the result from New Zealand (Emberson et al., 2016).

\section{DISCUSSION}

\section{Landslide-Induced Weathering Traced by $U$ Isotopes}

The decreasing $\left({ }^{234} \mathrm{U} /{ }^{238} \mathrm{U}\right)$ of the main Minjiang River samples from upstream to downstream (Figure 2) could be influenced by the lithologic variation of bedrock (Figure 1). To test this possibility, we examine how dissolved $\left({ }^{234} \mathrm{U} /{ }^{238} \mathrm{U}\right)$ vary with the $\mathrm{Ca} / \mathrm{Na}^{*}$ ratio of river water, with the latter being widely used to constrain the contribution of the weathering of different bedrock to riverine weathering flux, especially the contribution of carbonate weathering and silicate weathering (e.g., Gaillardet et al., 1999). However, the observed opposite trends between $\left({ }^{234} \mathrm{U} /{ }^{238} \mathrm{U}\right)$ ratios and $\mathrm{Ca} / \mathrm{Na}^{*}$ ratio for mainstream and tributary of Minjiang River (Figure 5) support that lithologic variations

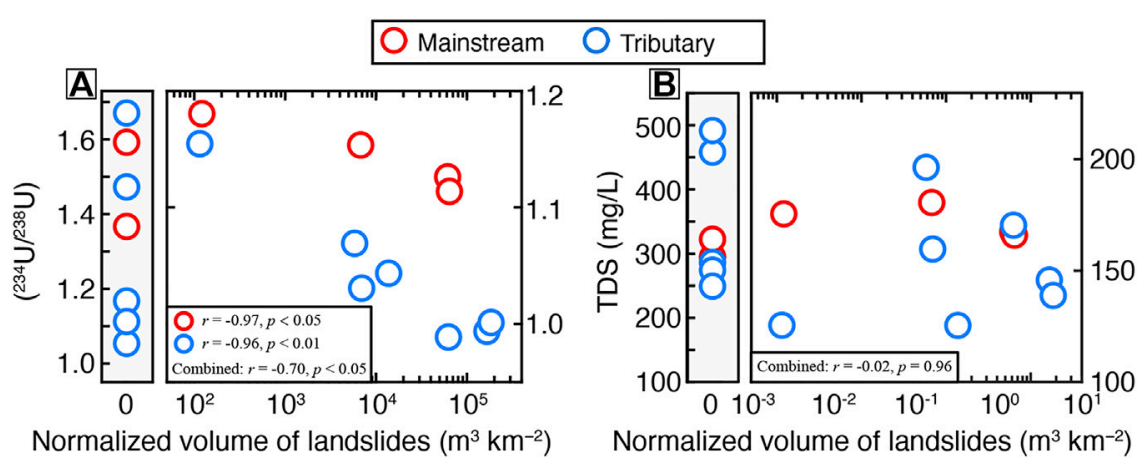

FIGURE 3|Relationships between the riverine dissolved $\left({ }^{234} \mathrm{U} /{ }^{238} \mathrm{U}\right)$ ratios $(\mathbf{A})$, TDS (B), and the fraction of normalized volume of landslides (LS norm) in the Minjiang River Basin. The $r$ in the bottom left represents the correlation coefficient for the linear fit of the circles with $L S_{\text {norm }}$ bigger than zero. The error bar for the $\left({ }^{234} U /{ }^{238} U\right)$ ratio is smaller than the size of the symbols.
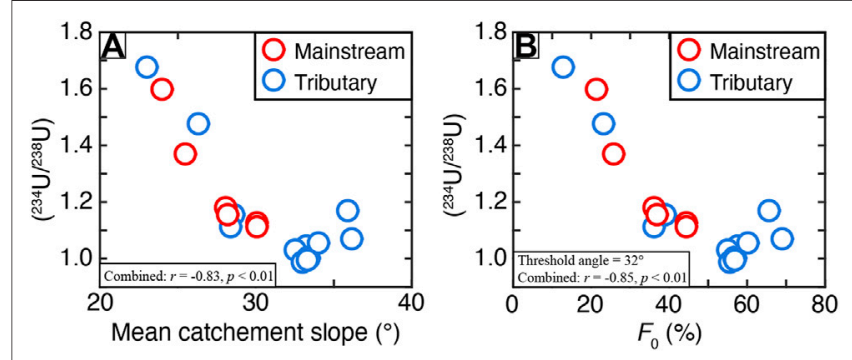

FIGURE 4 | Correlations between riverine $\left({ }^{234} U /{ }^{238} U\right)$ values and mean catchment slope angle (A) and the fraction of slopes steeper than the threshold angle $\left(F_{0}\right)(\mathbf{B})$ in the mainstream and tributary catchments of Minjiang River Basin. The $r$ in the bottom left represents the correlation coefficient for the linear fit of all circles. The error bar for the $\left({ }^{234} \mathrm{U} /{ }^{238} \mathrm{U}\right)$ ratio is smaller than the size of the symbols.

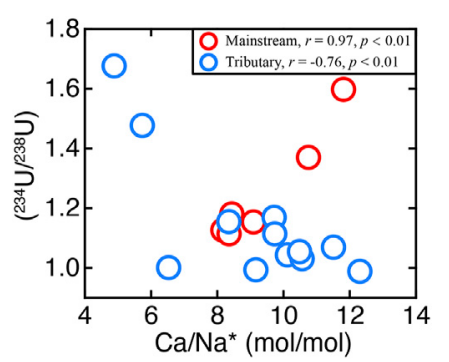

FIGURE 5 | Correlations between riverine $\left({ }^{234} U /{ }^{238} U\right)$ values and corrected $\mathrm{Ca} / \mathrm{Na}^{*}$ ratios in the mainstream and tributary catchments of Minjiang River Basin. The error bar for the $\left({ }^{234} \mathrm{U} /{ }^{238} \mathrm{U}\right)$ ratio is smaller than the size of the symbols. 
cannot explain the variation of riverine $\mathrm{U}$ isotope in the Minjiang Basin in a consistent way.

We attribute the observed decreasing $\left({ }^{234} \mathrm{U} /{ }^{238} \mathrm{U}\right)$ of the main Minjiang River samples to the increasing inputs of solutes produced by landslide-induced weathering. The co-seismic landslides triggered by the $2008 M_{w} 7.9$ Wenchuan earthquake represent the most recent major landslide-triggering event in the Minjiang River Basin and the density of these co-seismic landslides increases from upstream to downstream along the main Minjiang valley (Figure 1). Freshly fragmented rocks, which are often produced by bedrock landsliding (Emberson et al., 2018), have a high proportion of unweathered and U-active minerals (White and Brantley, 2003), such as biotite and apatite. Rapid dissolution of these active minerals would release ${ }^{234} \mathrm{U}$ and ${ }^{238} \mathrm{U}$ congruently with only limited alpha-recoil ejection of ${ }^{234} \mathrm{U}$ from the decay of ${ }^{238} \mathrm{U}$, thus yielding a near-equilibrium $\left({ }^{234} \mathrm{U} /\right.$ $\left.{ }^{238} \mathrm{U}\right)$ ratio $(\sim 1)$ of the dissolved product from weathering of fresh landslide debris. Therefore, a prominent contribution of landslide-induced weathering fluxes to the downstream Minjiang River provides a plausible explanation for the lower riverine dissolved $\left({ }^{234} \mathrm{U} /{ }^{238} \mathrm{U}\right)$ ratios (Figure 2). In contrast, landslides are less frequent in the upstream Minjiang River where erosion rates are low and regolith weathering likely dominates the total weathering fluxes. In those settings, recoil ejection of ${ }^{234} \mathrm{U}$ from the accumulated weathering residue in the regolith would cause accumulation of ${ }^{234} \mathrm{U}$ and thus high $\left({ }^{234} \mathrm{U} /\right.$ ${ }^{238} \mathrm{U}$ ) ratios in solutes ( $\mathrm{Li}$ et al., 2018), thus explaining the high $\left({ }^{234} \mathrm{U} /{ }^{238} \mathrm{U}\right)$ ratios of the river water samples from the upstream Minjiang River (Figure 2).

We evaluate the influence of landslides on the riverine ${ }^{234} \mathrm{U} /$ ${ }^{238} \mathrm{U}$ using the normalized volume of landslides $\left(\mathrm{LS}_{\text {norm }}\right)$ in the catchment (e.g., Emberson et al., 2016). The negative correlation between $\left({ }^{234} \mathrm{U} /{ }^{238} \mathrm{U}\right)$ ratio and $\mathrm{LS}_{\text {norm }}$ in the studied catchments of the Minjiang River Basin (Figure 3A) is expected from the previous explanation of ${ }^{234} \mathrm{U} /{ }^{238} \mathrm{U}$ fractionation during mineral dissolution, likely revealing a control of bedrock landsliding on the riverine $\left({ }^{234} \mathrm{U} /{ }^{238} \mathrm{U}\right)$ ratio with low $\left({ }^{234} \mathrm{U} /{ }^{238} \mathrm{U}\right)$ in solutes dominated by landslide-induced weathering fluxes.

The normalized volume of landslides $\left(\mathrm{LS}_{\text {norm }}\right)$ is determined from the mapped co-seismic landslides triggered by the 2008 Wenchuan earthquake (Li et al., 2014), but does not account for the historical landslides occurring before the earthquake. Those landslide deposits may get revegetated but remain in the catchments (Pearce and Watson, 1986; Wang et al., 2015), being continuously weathered and contributing to solute fluxes. With that in mind, we adopt two other metrics for landslide activities: mean catchment slope angle and the fraction of slopes greater than the threshold angle. Mean catchment slope angles reflect topographic steepness and scale positively with erosion rates (Ouimet et al., 2009). Catchments with higher mean slope angles generally have faster erosion rates whereas bedrock landslides occur more frequently on slopes steeper than threshold angles (Ouimet et al., 2009; Clarke and Burbank, 2010). Therefore, the mean catchment slope angle could reveal landslide activities to first order. Similarly, the fraction of slopes steeper than the threshold angle $\left(F_{o}\right)$ represents the extent of steep landscapes prone to landslides in a catchment, providing

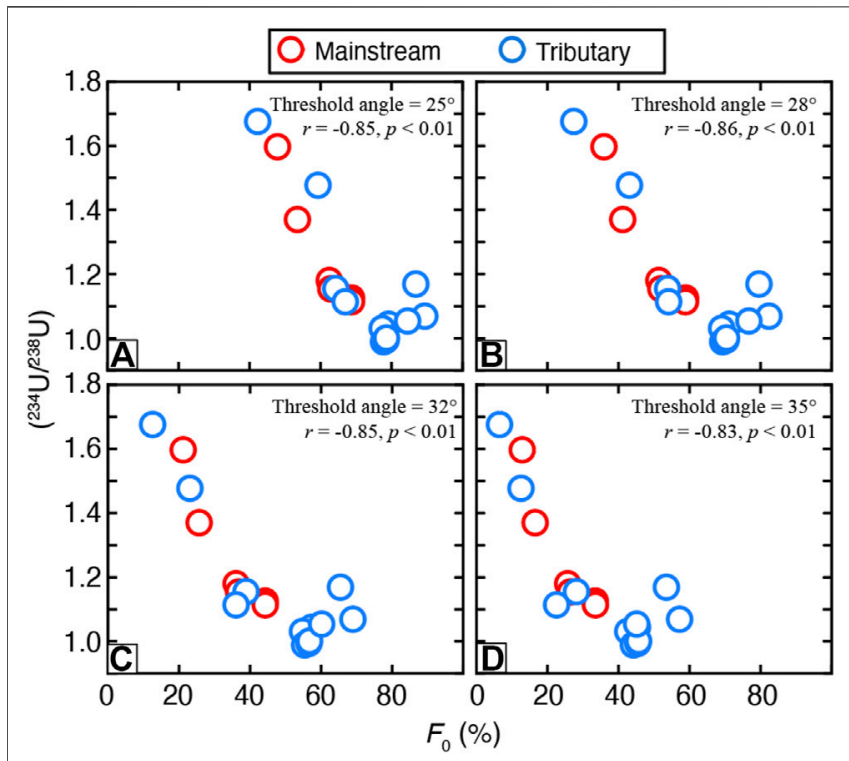

FIGURE 6 | Correlations between riverine $\left({ }^{234} U / 238 \mathrm{U}\right)$ values and the fraction of slopes steeper than the threshold angle $\left(F_{0}\right)$ under different values of applied threshold angle in the mainstream and tributary catchments of Minjiang River Basin. Panel (C) is the same as Panel 4B except for the range of the $X$-axis. The $r$ in the top right represents the correlation coefficient for the linear fit of all circles. The error bar for the $\left({ }^{234} \mathrm{U} /{ }^{238} \mathrm{U}\right)$ ratio is smaller than the size of the symbols.

another useful metric for landslide activities. That said, the significant negative correlations between the riverine dissolved $\left({ }^{234} \mathrm{U} /{ }^{238} \mathrm{U}\right)$ ratios and mean catchment slope angle (Figure 4A) and the fraction of steeper-than-threshold-angle slopes (Figure 4B) reveal the influence of landslide activities on the riverine ${ }^{234} \mathrm{U} /{ }^{238} \mathrm{U}$ signals through their effects on chemical weathering. We note that varying the chosen threshold angle within $25-35^{\circ}$ does not affect the correlation between $\left({ }^{234} \mathrm{U} /{ }^{238} \mathrm{U}\right)$ ratios and $F_{o}$ (Figures 6A-D). Overall, our observations support using the riverine ${ }^{234} \mathrm{U} /{ }^{238} \mathrm{U}$ to trace landslide-induced weathering fluxes.

\section{Landslide Activity and TDS}

TDS is another useful tool to trace landslide-induced weathering. For example, Emberson et al. (2016) found a strong positive correlation between TDS and normalized landslide volume, indicating the control of landslide-induced weathering on TDS. However, TDS seems not able to reflect landslideinduced weathering fluxes in the Minjiang River Basin, since no clear relationship exists between TDS and $\mathrm{LS}_{\text {norm }}$ (Figure 3B). We tentatively attribute the silent response of TDS to LS $_{\text {norm }}$ in the Minjiang River Basin to the complicated lithology. The main bedrocks in the upper stream of the Minjiang River are Triassic meta-sediment that usually contains abundant carbonate minerals and Paleozoic carbonate rocks/basalts (Figure 1). Weathering of carbonate minerals is generally fast and can quickly increase TDS, providing a non-landslide mechanism to boost TDS (Jacobson et al., 2003). Our results suggest that accounting for lithological variations and separating carbonate 
and silicate weathering are critical for understanding how landslides impact chemical weathering. Quantifying weathering budgets of different rocks is beyond the scope of this study, but we emphasize that this represents an important future research direction in studies of weathering processes in landslideprone areas.

\section{Implications for Weathering Kinetics and the "Uplift-Weathering" Hypothesis}

The near-equilibrium dissolved $\left({ }^{234} \mathrm{U} /{ }^{238} \mathrm{U}\right)$ ratios in the Minjiang River Basin and their correlations with the metrics for landslide activities suggest that landslide-induced weathering fluxes may have major contributions to the total solute fluxes in an active mountain range. Future studies based on our findings could provide new insights into the theories of weathering kinetics, especially into our understanding of how silicate weathering rates respond to changes in physical erosion rates.

Modern observations from small catchments suggest that silicate weathering rates may be limited by weathering kinetics in rapidly eroding settings (West et al., 2005; West, 2012). In this framework, when erosion rates are high, silicate weathering rates do not increase with erosion rates but are regulated by climatic factors (e.g., precipitation and temperature) (West et al., 2005; West, 2012). On the other hand, the observations of ridgetop soils from New Zealand show that chemical weathering rates increase proportionally with physical erosion rates (Larsen et al., 2014), suggesting no kinetic limitations of weathering reactions. Reconciling the different observations from catchments versus from soils is critical for a better understanding of the role of tectonic uplift in the global carbon cycle and Earth's climate (Raymo et al., 1988; Raymo and Ruddiman, 1992; Goddéris et al., 2017; Li et al., 2021). In this context, the roles of different geomorphic processes, especially landslides, have not been explicitly considered yet.

Our results shed light on the weathering-erosion coupling by demonstrating that landslides could make a major contribution to riverine solute fluxes. Which cannot be captured by the studies of soil profiles. Studies have shown that landslides dominate sediment budgets in uplifting mountains (Hovius et al., 1997; Li G. et al., 2017; Marc et al., 2019) and that landslide volumes scale with chemical weathering rates (Emberson et al., 2016), suggesting a major role of landslides in erosion and weathering in rapidly-eroding mountains. Thus, landslide-induced weathering may represent an under-appreciated weathering mechanism with global-scale impacts. Resolving landslide-induced weathering fluxes relies on the development of process-based models (e.g., Lebedeva et al., 2007; Ferrier and Kirchner, 2008; Hilley et al., 2010; West, 2012; Croissant et al., 2021; Li and Moon, 2021) and effective tracers such as the dissolved uranium isotopes presented in this study. Future studies are needed to better understand how weathering rates respond to landslide activities across different conditions and to separate contributions from soils versus landslides, as well as from different lithologies (e.g., carbonates and silicates), in weathering budgets.

The outcomes from these research efforts would advance our understanding of how tectonic uplift controls silicate weathering and Earth's climate. In this context, our work demonstrates that the riverine dissolved ${ }^{234} \mathrm{U} /{ }^{238} \mathrm{U}$ directly links to landslide activities in a river basin where conventional water chemistry metric TDS cannot trace landslide-induced weathering fluxes, providing a promising tool to better understand landslide-driven weathering processes in catchments with complex lithologies.

\section{CONCLUSION}

We compiled the riverine dissolved radiogenic uranium isotopes $\left({ }^{234} \mathrm{U} /{ }^{238} \mathrm{U}\right)$ of a group of landslide-impacted catchments in the Minjiang River Basin and compared the results to the derived metrics of landslide activity for each catchment. We found that the dissolved $\left({ }^{234} \mathrm{U} /{ }^{238} \mathrm{U}\right)$ has negative correlations with the inferred landslide activities, reflecting the influence of landslide-induced weathering on the riverine dissolved $\left({ }^{234} \mathrm{U} /{ }^{238} \mathrm{U}\right)$. We propose that the riverine ${ }^{234} \mathrm{U} /{ }^{238} \mathrm{U}$ ratio provides a promising tracer of landslide-induced weathering fluxes in landslide-prone landscapes. Whereas landslides may have a major role in controlling weathering fluxes from uplifting mountains, future studies are needed to unravel the mechanism of landslide-induced weathering and how that differs from weathering in regolith zones. The outcomes would provide new insights into how tectonic uplift and erosion impact chemical weathering and the environmental impacts of tectonic uplift.

\section{DATA AVAILABILITY STATEMENT}

The original contributions presented in the study are included in the article/Supplementary Material, further inquiries can be directed to the corresponding author.

\section{AUTHOR CONTRIBUTIONS}

GJL designed and organized the work. LFL and LL collected the data. LFL and GKL wrote the text. All authors take part in the discussion.

\section{FUNDING}

This work is supported by The Second Tibetan Plateau Scientific Expedition and Research (STEP) program (Grant No. 2019QZKK0707), Natural Science Foundation of China (No. 41991321, 42061130212, 41877351, 41761144058, and 41730101), and Fundamental Research Funds for the Central Universities (NO. 0206-14380124).

\section{ACKNOWLEDGMENTS}

We thank the editor and two reviewers for their careful editorial work and constructive suggestions to this paper. 


\section{REFERENCES}

Bourdon, B., Turner, S., Henderson, G. M., and Lundstrom, C. C. (2003). 1. Introduction to U-Series Geochemistry. Rev. Mineralogy Geochem. 52 (1), 1-22. doi:10.1515/9781501509308-006

Burbank, D. W., Leland, J., Fielding, E., Anderson, R. S., Brozovic, N., Reid, M. R., et al. (1996). Bedrock Incision, Rock Uplift and Threshold Hillslopes in the Northwestern Himalayas. Nature 379 (6565), 505-510. doi:10.1038/379505a0

Chabaux, F., Riotte, J., and Dequincey, O. (2003). 13. U-Th-Ra Fractionation during Weathering and River Transport. Rev. Mineralogy Geochem. 52 (1), 533-576. doi:10.1515/9781501509308-018

Clarke, B. A., and Burbank, D. W. (2010). Bedrock Fracturing, Threshold Hillslopes, and Limits to the Magnitude of Bedrock Landslides. Earth Planet. Sci. Lett. 297 (3), 577-586. doi:10.1016/j.epsl.2010.07.011

Croissant, T., Hilton, R. G., Li, G. K., Howarth, J., Wang, J., Harvey, E. L., et al. (2021). Pulsed Carbon export from Mountains by Earthquake-Triggered Landslides Explored in a Reduced-Complexity Model. Earth Surf. Dynam. 9 (4), 823-844. doi:10.5194/esurf-9-823-2021

Deng, K., Wittmann, H., Yang, S., and Blanckenburg, F. (2021). The Upper Limit of Denudation Rate Measurement from Cosmogenic ${ }^{10} \mathrm{Be}$ (Meteoric) $/{ }^{9} \mathrm{Be}$ Ratios in Taiwan. J. Geophys. Res. Earth Surf. 126 (10), e2021JF006221. doi:10.1029/ 2021jf006221

Emberson, R., Galy, A., and Hovius, N. (2017). Combined Effect of Carbonate and Biotite Dissolution in Landslides Biases Silicate Weathering Proxies. Geochimica et Cosmochimica Acta 213, 418-434. doi:10.1016/j.gca.2017.07.014

Emberson, R., Galy, A., and Hovius, N. (2018). Weathering of Reactive Mineral Phases in Landslides Acts as a Source of Carbon Dioxide in Mountain Belts. J. Geophys. Res. Earth Surf. 123, 2695-2713. doi:10.1029/2018jf004672

Emberson, R., Hovius, N., Galy, A., and Marc, O. (2016). Chemical Weathering in Active Mountain Belts Controlled by Stochastic Bedrock Landsliding. Nat. Geosci 9 (1), 42-45. doi:10.1038/ngeo2600

Fan, X., Scaringi, G., Korup, O., West, A. J., Westen, C. J., Tanyas, H., et al. (2019). Earthquake-Induced Chains of Geologic Hazards: Patterns, Mechanisms, and Impacts. Rev. Geophys. 57 (2), 421-503. doi:10.1029/2018rg000626

Ferrier, K. L., and Kirchner, J. W. (2008). Effects of Physical Erosion on Chemical Denudation Rates: A Numerical Modeling Study of Soil-Mantled Hillslopes. Earth Planet. Sci. Lett. 272 (3-4), 591-599. doi:10.1016/j.epsl.2008.05.024

Gaillardet, J., Dupré, B., Louvat, P., and Allègre, C. J. (1999). Global Silicate Weathering and $\mathrm{CO}_{2}$ Consumption Rates Deduced from the Chemistry of Large Rivers. Chem. Geology. 159 (1-4), 3-30. doi:10.1016/s0009-2541(99) 00031-5

Goddéris, Y., Donnadieu, Y., Carretier, S., Aretz, M., Dera, G., Macouin, M., et al. (2017). Onset and Ending of the Late Palaeozoic Ice Age Triggered by Tectonically Paced Rock Weathering. Nat. Geosci. 10, 382-386.doi:10.1038/ ngeo2931

Hilley, G. E., Chamberlain, C. P., Moon, S., Porder, S., and Willett, S. D. (2010). Competition between Erosion and Reaction Kinetics in Controlling SilicateWeathering Rates. Earth Planet. Sci. Lett. 293 (1), 191-199. doi:10.1016/j.epsl. 2010.01.008

Hovius, N., Stark, C. P., and Allen, P. A. (1997). Sediment Flux from a Mountain belt Derived by Landslide Mapping. Geol 25 (3), 231-234. doi:10.1130/00917613(1997)025<0231:sffamb > 2.3.c0;2

Jacobson, A. D., Blum, J. D., Chamberlain, C. P., Craw, D., and Koons, P. O. (2003). Climatic and Tectonic Controls on Chemical Weathering in the New Zealand Southern Alps. Geochimica et Cosmochimica Acta 67 (1), 29-46. doi:10.1016/ s0016-7037(02)01053-0

Jin, Z., West, A. J., Zhang, F., An, Z., Hilton, R. G., Yu, J., et al. (2016). Seismically Enhanced Solute Fluxes in the Yangtze River Headwaters Following the A.D. 2008 Wenchuan Earthquake. Geology 44 (1), 47-50. doi:10.1130/g37246.1

Keefer, D. K. (1994). The Importance of Earthquake-Induced Landslides to LongTerm Slope Erosion and Slope-Failure Hazards in Seismically Active Regions. Geomorphology 10, 265-284. doi:10.1016/b978-0-444-82012-9.50022-0

Larsen, I. J., Almond, P. C., Eger, A., Stone, J. O., Montgomery, D. R., and Malcolm, B. (2014). Rapid Soil Production and Weathering in the Southern Alps, New Zealand. Science 343 (6171), 637-640. doi:10.1126/science.1244908

Larsen, I. J., and Montgomery, D. R. (2012). Landslide Erosion Coupled to Tectonics and River Incision. Nat. Geosci 5 (7), 468-473. doi:10.1038/ngeo1479
Lebedeva, M. I., Fletcher, R. C., Balashov, V. N., and Brantley, S. L. (2007). A Reactive Diffusion Model Describing Transformation of Bedrock to Saprolite. Chem. Geology. 244 (3-4), 624-645. doi:10.1016/j.chemgeo.2007.07.008

Li, G. K., and Moon, S. (2021). Topographic Stress Control on Bedrock Landslide Size. Nat. Geosci. 14 (5), 307-313. doi:10.1038/s41561-02100739-8

Li, G., West, A. J., Densmore, A. L., Hammond, D. E., Jin, Z., Zhang, F., et al. (2016). Connectivity of Earthquake-Triggered Landslides with the Fluvial Network: Implications for Landslide Sediment Transport after the 2008 Wenchuan Earthquake. J. Geophys. Res. Earth Surf. 121 (4), 703-724. doi:10.1002/ 2015jf003718

Li, G., West, A. J., Densmore, A. L., Jin, Z., Parker, R. N., and Hilton, R. G. (2014). Seismic Mountain Building: Landslides Associated with the 2008 Wenchuan Earthquake in the Context of a Generalized Model for Earthquake Volume Balance. Geochem. Geophys. Geosyst. 15 (4), 833-844. doi:10.1002/ $2013 \mathrm{gc005067}$

Li, G., West, A. J., Densmore, A. L., Jin, Z., Zhang, F., Wang, J., et al. (2017a). Earthquakes Drive Focused Denudation along a Tectonically Active Mountain Front. Earth Planet. Sci. Lett. 472, 253-265. doi:10.1016/j.epsl.2017.04.040

Li, G., West, A. J., and Qiu, H. (2019a). Competing Effects of Mountain Uplift and Landslide Erosion over Earthquake Cycles. J. Geophys. Res. Solid Earth 124 (5), 5101-5133. doi:10.1029/2018jb016986

Li, L., Chen, J., Chen, T., Chen, Y., Hedding, D. W., Li, G., et al. (2018). Weathering Dynamics Reflected by the Response of Riverine Uranium Isotope Disequilibrium to Changes in Denudation Rate. Earth Planet. Sci. Lett. 500, 136-144. doi:10.1016/j.epsl.2018.08.008

Li, L., Liu, X., Li, T., Li, L., Zhao, L., Ji, J., et al. (2017b). Uranium Comminution Age Tested by the Eolian Deposits on the Chinese Loess Plateau. Earth Planet. Sci. Lett. 467, 64-71. doi:10.1016/j.epsl.2017.03.014

Li, S., Goldstein, S. L., and Raymo, M. E. (2021). Neogene continental Denudation and the Beryllium Conundrum. Proc. Natl. Acad. Sci. 118 (42), 265-284. doi:10. 1073/pnas.2026456118

Li, S., Li, W., Beard, B. L., Raymo, M. E., Wang, X., Chen, Y., et al. (2019b). K Isotopes as a Tracer for continental Weathering and Geological K Cycling. Proc. Natl. Acad. Sci. 116 (18), 8740-8874. doi:10.1073/pnas.1811282116

Marc, O., Behling, R., Andermann, C., Turowski, J. M., Illien, L., Roessner, S., et al. (2019). Long-term Erosion of the Nepal Himalayas by Bedrock Landsliding: the Role of Monsoons, Earthquakes and Giant Landslides. Earth Surf. Dynam. 7 (1), 107-128. doi:10.5194/esurf-7-107-2019

Marc, O., Hovius, N., and Meunier, P. (2016). The Mass Balance of Earthquakes and Earthquake Sequences. Geophys. Res. Lett. 43 (8), 3708-3716. doi:10.1002/ $2016 \mathrm{gl} 068333$

Ouimet, W. B., Whipple, K. X., Crosby, B. T., Johnson, J. P., and Schildgen, T. F. (2008). Epigenetic Gorges in Fluvial Landscapes. Earth Surf. Process. Landforms 33 (13), 1993-2009. doi:10.1002/esp.1650

Ouimet, W. B., Whipple, K. X., and Granger, D. E. (2009). Beyond Threshold Hillslopes: Channel Adjustment to Base-Level Fall in Tectonically Active Mountain Ranges. Geology 37 (7), 579-582. doi:10.1130/g30013a.1

Parker, R. N., Densmore, A. L., Rosser, N. J., de Michele, M., Li, Y., Huang, R., et al. (2011). Mass Wasting Triggered by the 2008 Wenchuan Earthquake Is Greater Than Orogenic Growth. Nat. Geosci 4 (7), 449-452. doi:10.1038/ ngeo 1154

Pearce, A. J., and Watson, A. J. (1986). Effects of Earthquake-Induced Landslides on Sediment Budget and Transport over a 50-yr Period. Geol 14 (1), 52-55. doi:10.1130/0091-7613(1986) 14<52:eoelos >2.0.co;2

Raymo, M. E., Ruddiman, W. F., and Froelich, P. N. (1988). Influence of Late Cenozoic Mountain Building on Ocean Geochemical Cycles. Geol 16 (7), 649-653. doi:10.1130/0091-7613(1988)016<0649:iolcmb $>2.3$

Raymo, M. E., and Ruddiman, W. F. (1992). Tectonic Forcing of Late Cenozoic Climate. Nature 359 (6391), 117-122. doi:10.1038/359117a0

Robinson, L. F., Henderson, G. M., Hall, L., and Matthews, I. (2004). Climatic Control of Riverine and Seawater Uranium-Isotope Ratios. Science 305 (5685), 851-854. doi:10.1126/science.1099673

Torres, M. A., West, A. J., and Clark, K. E. (2015). Geomorphic Regime Modulates Hydrologic Control of Chemical Weathering in the Andes-Amazon. Geochimica et Cosmochimica Acta 166, 105-128. doi:10.1016/j.gca.2015.06.007

Vigier, N., Burton, K. W., Gislason, S. R., Rogers, N. W., Duchene, S., Thomas, L., et al. (2006). The Relationship between Riverine U-Series Disequilibria and 
Erosion Rates in a Basaltic Terrain. Earth Planet. Sci. Lett. 249 (3-4), 258-273. doi:10.1016/j.epsl.2006.07.001

von Blanckenburg, F., Bouchez, J., and Wittmann, H. (2012). Earth Surface Erosion and Weathering from the 10Be (meteoric)/9Be Ratio. Earth Planet. Sci. Lett. 351-352, 295-305. doi:10.1016/j.epsl.2012.07.022

Wang, J., Jin, Z., Hilton, R. G., Zhang, F., Densmore, A. L., Li, G., et al. (2015). Controls on Fluvial Evacuation of Sediment from Earthquake-Triggered Landslides. Geology 43 (2), 115-118. doi:10.1130/g36157.1

Wang, R.-M., and You, C.-F. (2013). Precise Determination of U Isotopic Compositions in Low Concentration Carbonate Samples by MC-ICP-MS. Talanta 107, 67-73. doi:10.1016/j.talanta.2012.12.044

West, A. J., Galy, A., and Bickle, M. (2005). Tectonic and Climatic Controls on Silicate Weathering. Earth Planet. Sci. Lett. 235 (1-2), 211-228. doi:10.1016/j. epsl.2005.03.020

West, A. J. (2012). Thickness of the Chemical Weathering Zone and Implications for Erosional and Climatic Drivers of Weathering and for Carbon-Cycle Feedbacks. Geology 40, 811-814. doi:10.1130/g33041.1

White, A. F., and Brantley, S. L. (2003). The Effect of Time on the Weathering of Silicate Minerals: Why Do Weathering Rates Differ in the Laboratory and Field. Chem. Geology. 202 (3), 479-506. doi:10.1016/j.chemgeo.2003.03.001
Ye, T., Huang, S., and Deng, Z. (2017). Spatial Database of 1: 2500000 Digital Geologic Map of People's Republic of China. Geology. China 44 (S1), 24-31. doi:10.12029/gc2017Z103

Conflict of Interest: The authors declare that the research was conducted in the absence of any commercial or financial relationships that could be construed as a potential conflict of interest.

Publisher's Note: All claims expressed in this article are solely those of the authors and do not necessarily represent those of their affiliated organizations, or those of the publisher, the editors, and the reviewers. Any product that may be evaluated in this article, or claim that may be made by its manufacturer, is not guaranteed or endorsed by the publisher.

Copyright $\odot 2022 \mathrm{Li}, \mathrm{Li}, \mathrm{Li}$ and Li. This is an open-access article distributed under the terms of the Creative Commons Attribution License (CC BY). The use, distribution or reproduction in other forums is permitted, provided the original author(s) and the copyright owner(s) are credited and that the original publication in this journal is cited, in accordance with accepted academic practice. No use, distribution or reproduction is permitted which does not comply with these terms. 